\title{
Study on E-Government Services Quality: The Integration of Online and Offline Services
}

\author{
Jing Fan, Wenting Yang \\ International Business School, Beijing Foreign Studies University, Beijing (China) \\ fanjing@bfssu.edu.cn,yangwenting@,bfsu.edu.cn
}

Received: January 2015

Accepted: March 2015

\section{Abstract:}

Purpose: E-Government, as a new bond linking the government and the public, has gradually become the focus of innovation in government services. The paper focuses on the e-Government service quality issues from the perspective of users.

Design/methodology/approach: From the aspects of online service quality perception and offline service quality perception, based on IS Success model and SERQUAL model, e-Government Services Quality model has been set up with information quality, system quality and service quality as key factors. Then, the survey method was applied to collect data and then to test the model.

Findings: It was found that users' perception of offline service quality has a significant effect on improving their perception of online service quality, and online service quality perception has a significant effect on public satisfaction of e-Government services; information clarity, system security and stability, interactive services and "one-stop" services all have a significant effect on public satisfaction of e-Government services. However, offline service quality perception has certain positive effect on public satisfaction of e-Government services but not dramatically. 
Research limitations/implications: Mobile e-Government as an important direction of the development of e-Government, in the future, we will study more about mobile e-Government services channels.

Originality/value: This study further develops the theory of information system service quality, and also provides a theoretical reference for government departments. On the one hand, based on the characteristics of e-government system, information quality, system quality and service quality in the previous system service model are further discussed; on the other hand, both online and offline services are taken into consideration in the information system service model, thus establishing the e-government services quality model and making an indepth study of the integration effect of online and offline services. Its conclusions can be references for the application of traditional information system service model in the field of e-government.

Keywords: e-government, citizens' satisfaction, online government service quality perception, offline government service quality perception

\section{Introduction}

In the 1990s, the United States launched a National Performance Review movement, at the same time, announced to implement the National Information Infrastructure Plan, which made building an electronic government (e-Government) as an important direction of government governance reform. In the last 10 years, e-Government has been widely seen as a powerful strategy for governance reform by governments all over the world.

There are two major reasons for the push of e-Government by governments around the world. On the one hand, it's the rise of new public management theory in the 1960s and 1970s, which holds that government is the provider of services, citizens and enterprises are customers to enjoy services, and governments should be customer-oriented, converting their functions from management orientation to service orientation (Layne \& Lee, 2001). On the other hand, with the rapid development of information technology, governments try to enable citizens and enterprises to access government services and information efficiently and effectively, as well as improving transparency, accountability and governance capacity of governments through the Internet and other IT communication channels (Aikins \& Krane, 2010).

The construction of e-Government in China started with the "Government Internet Project" in 1999. In 2003, the State Council Informatization Office formally began to construct e-Government Intranet and extranet, government portal website, four basic databases and twelve business systems as a priority (Ma, Chung \& Thorson, 2005). So far, various 
government departments in China not only have built thousands of government portal websites, but also have achieved rapid development on e-Government system interactivity, collaboration, and integration of infrastructure between different departments (Fan, Zhang \& Yen, 2014).

However, experts point out that the idea that construction values more than application is always the prominent problem in the development of electronic government in China. Citizens and enterprises' application of e-Government services is still relatively low. Data show that the utilization rate of citizen-oriented e-Government in China is only $5 \%$, with most of e-Government tend to sit idle, however, the utilization rate is $35 \%$ in the United States (Wang, 2000).

Before the establishment of e-Government system, government services mainly depend on traditional offline service, which is a kind of services where government staffs and citizens communicate face to face. However, pure e-Government is a kind of online services, where government staffs do not need to meet with citizens with the use of Internet technology, thus reducing the management cost, improving the management efficiency, greatly promoting the synergy between different departments, and improving the efficiency of services (Pieterson \& Ebbers, 2008).

However, most previous studies focused on issues related to government departments to promote e-Government services and the success of e-Government system, the study on e-Government users is relatively small. Even though some papers studied the factors influencing citizens or companies to adopt e-Government, few studies have studied e-Government service quality issues from the perspective of users (Bélanger \& Carter, 2008; Hung, Chang \& Kuo, 2013).

At the same time, due to the imbalance between the distribution of IT resources and citizens' ability of use, there often exists cases where online and offline services coexist or in series in the process of e-Government in action. In coexistence case, many businesses can be selected via online and offline in one of two ways, such as citizens to apply for exit permits. In tandem case, some parts of the business need to be done through online submission, while other parts need to be dealt with to the scene offline, such as filing personal income tax. As a result, online and offline business formed an integrated effect on citizens' perception of services quality (Lee, Kim \& Anh, 2011).

Therefore, based on theories of predecessors on information system service quality, this study consists of two aspects: on the one hand, based on the characteristics of e-Government system, information quality, system quality and service quality in the previous system service model are further discussed; on the other hand, both online and offline services are taken into consideration in the original information system service model, thus establishing the e-Government services quality model and making an in-depth study of the integration effect of 
online and offline services. Its conclusions can be references for the application of traditional information system service model in the field of e-Government.

This article is organized as follows: Section 2 describes the research background and puts forward the study question once again; Section 3 proposes the conceptual model, theoretical model of e-Government services quality, as well as its research hypotheses. Section 4 illustrates its research methods and ideas; Section 5 introduces the reliability, validity, and results of the testing model in detail; Section 6 holds an in-depth discussion on data analysis results; And Section 7 presents the main conclusions of this study.

\section{Theoretical Backgrounds and Model Development}

\subsection{E-Government Services}

Users of e-Government can be of two types: citizens and enterprises. According to the life cycle theory of government services (Tang, Wu \& Zhang, 2007), for citizens, e-Government services mainly include birth declaration, education registration, social insurance, tax returns and other business; for enterprises, e-Government services mainly include enterprise registration, tax declaration, customs, intrastate declaration and other businesses. Larsen and Rainie (2002) pointed out that e-Government services include access to government information, access to government forms and services, release of policy information, employment and business opportunities and election information, archival files of tax, registration, signing a contract, paying a fine, and submissions for all kinds of advice to the government. The emergence of e-Government makes the process of the above services become faster and more convenient and more efficient, and increases government transparency and accountability.

With the advancement of e-Government, e-Government service levels are getting higher and higher. Layne and Lee (2001) provided a comprehensive growth model to reflect development stages of Electronic Government which have been categorized in four groups including catalogue, transaction, vertical integration and horizontal integration. It mutually indicated a continuous process of development. The Layne and Lee Model is shown in Figure 1. E-Government services here mainly refer to interaction services with input and output in specific businesses which government departments dealing with for citizens or enterprises, and not just for the presentation and dissemination of information.

At present, a large number of researchers are keen to study government internal information construction, information sharing between government departments and vertical business standardization and horizontal business integration from the perspective of government departments (Fan et al., 2014; Luna-Reyes, Gil-Garcia \& Cruz, 2007; Otjacques, Hitzelberger \& 
Feltz, 2007; Yang \& Maxwell, 2011; Pardo \& Tayi, 2007). At the same time, from the perspective of citizens, a large number of literature focus on the citizens' adoption of eGovernment (Carter \& Bélanger, 2005; Hung et al., 2013; Lee et al., 2011; Lin, Fofanah \& Liang 2011).

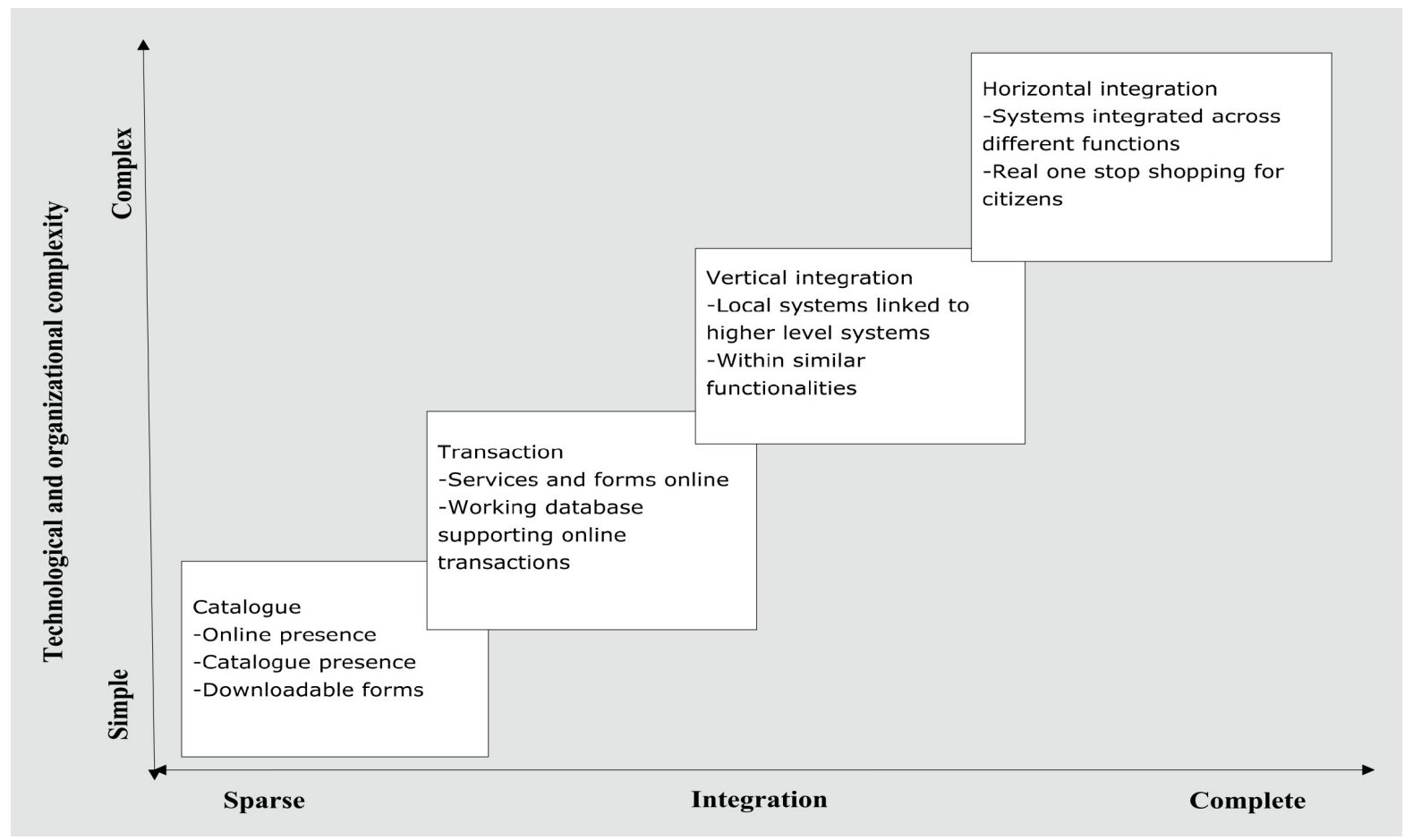

Figure 1. The Layne and Lee model (2001)

Government departments have invested heavily in the process of government services, especially in e-Government services. Because of the failure of many information system projects, it's very important to pay attention to the quality and efficiency of e-Government services (Goldfinch, 2007). Some studies have shown that, the level that government departments to provide customers with information technology service lags behind that of private sectors (Morgeson \& Mithas, 2009). Therefore, we should give more attention to e-government services.

However, on the one hand, levels of e-government service not only depend on the quality of the e-Government system itself which have been built up by governments, but also on citizens' ability to possess and obtain IT resources (Hu, Shi, Pan \& Wang, 2012). In China, capacities of IT resource vary greatly between regions, and in terms of access to IT resources, which are quite different between citizens of different educational backgrounds and between enterprises of different sizes (Reddick \& Turner, 2012). On the other hand, many services, especially ones need to provide original documents, such as original invoice, original passport, at present has yet to achieve full online processing. Part of the process need to be completed online, and 
other processes still need to be done on-site. This determines that not all businesses can be totally dependent on online channels (Pieterson \& Ebbers, 2008).

Furthermore, some researchers have pointed out that the success of e-Government cannot rely solely on technology, but rely more on people's behaviors (Akman, Yazici, Mishra \& Arifoglu, 2005; Wang \& Liao, 2008). Therefore, in this study, we have given full consideration to overlay effects of face to face service process in the government business on the quality of e-Government services.

\subsection{Information System Service Quality}

E-Government services affect many stakeholders including citizens and enterprises, government staffs, information technology developers and policy makers. Different stakeholders have different interests and goals, and these factors that may affect the adoption and success of e-Government services (Osman, Anouze, Hindi, Irani, Lee \& Weerakkody, 2014). In the existing literature, there is a great deal of researches on measuring the quality of e-Government services from the perspective of different stakeholders. However, most of these models' objective is to help policy makers and practitioners to evaluate and improve the quality of e-Government services, and few studies have measured users' perception of e-Government service from users' point of view (Wang, Bretschneider \& Gant, 2005). Therefore, in this study, we establish a conceptual model mainly from the perspective of users including citizens and enterprises.

The measurement of information system service quality efficiency is one of the most important research problems for both IS researchers and practitioners. A large number of scholars had done related research and discussion on information system service quality. One major theoretical basis is Information Systems Success Model. IS success model is first put forward by Delone \& McLean, which points out that system quality and information quality are the two main factors determining user satisfaction and the success of information system. These factors directly effects users response and users benefits; the updated model further pointed out that information quality, system quality and service quality together affect user satisfaction of information system and its ultimate benefits (Delone \& McLean, 2003), as shown in Figure 2. 


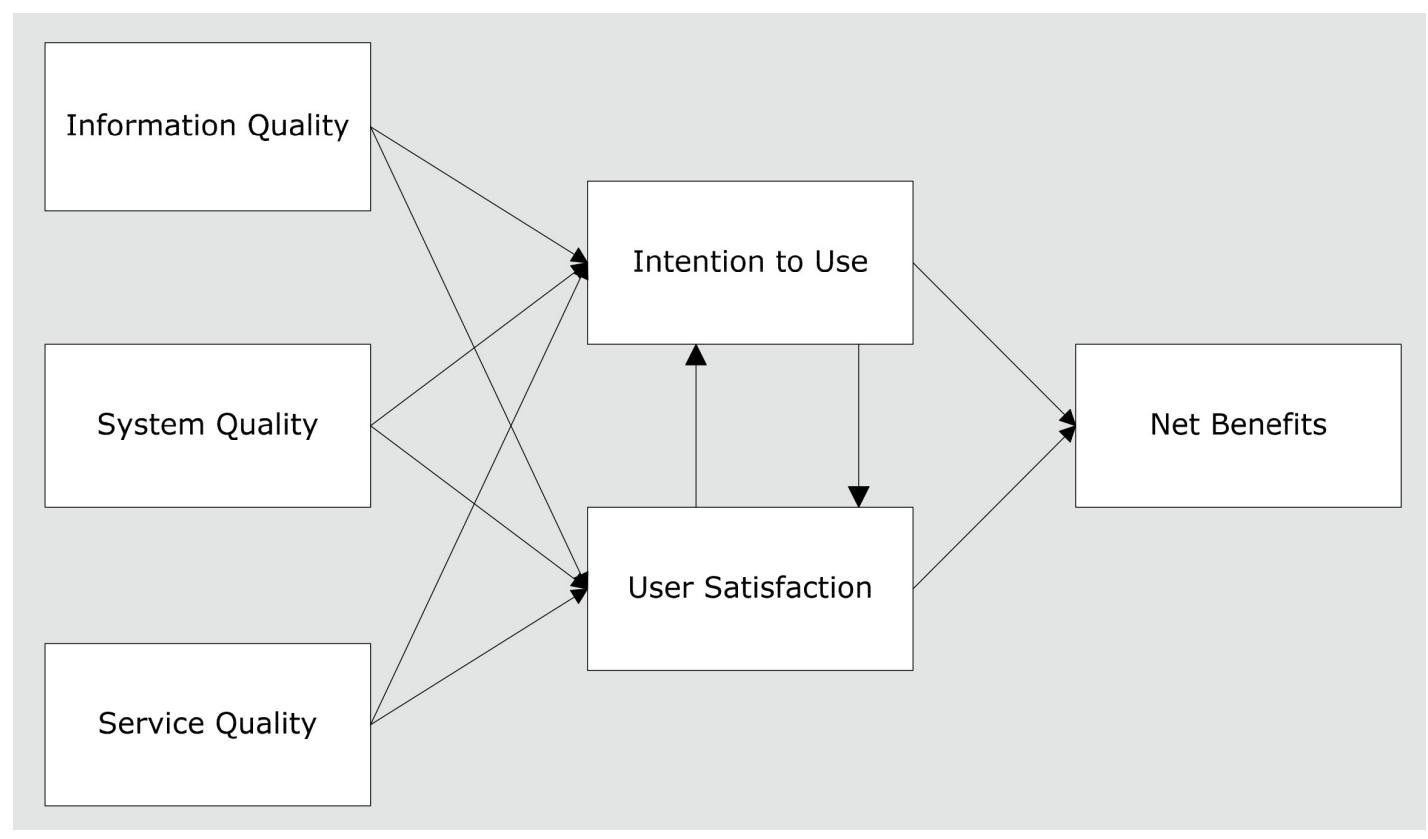

Figure 2. Information system success model (Delone \& McLean,2003)

At present there are relatively few empirical researches on citizens' response to e-Government services (Reddick \& Turner, 2012). However, it's very important to study that, this is because, compared with government services provided by other channels, the citizens' relative satisfaction to e-Government services determines the quality of e-Government services (Cohen, 2006).

Public satisfaction was first introduced in 1965 by Cardozo, referring to consumer perceptions of product or service performance compared with the expectations of a product or service (Cardozo, 1965). When users' perception of service level meets or exceeds their expected level, their satisfaction is high, and vice versa. Therefore, in this article, user satisfaction of e-government services is defined as following: enterprises and citizens' overall evaluation of online and offline services in the process of using e-government. It's the comprehensive feelings which are formed by public perception of using online services and using offline services. Civil service quality is users' perception produced in the process of dealing with business in the use of e-government, accumulating to form the e-government services satisfaction (Wang \& Liao, 2008).

In the field of e-government, the expected service quality is critical to user adoption of online services. Users' expected service quality in the online environment is not consistent with that in the traditional environment. In the tax business, it is possible to have situations where citizens or companies are satisfied with the existing traditional services, but in the online environment, this kind of situation may be entirely different. This is because citizens will have 
a new experience of online services which cannot be found in traditional environment (Hussein, Mohamed, Ahlan \& Mahmud, 2011).

Trace it to its source, the definition of quality of service first appeared in the field of marketing (Parasuraman, Zeithaml \& Malhotra, 2005), and then a famous description of the quality of service features, SERQUAL scale, was formed. SERQUAL is mainly in five dimensions, tangibles, reliability, responsiveness, assurance, and empathy to measure various aspects of the quality of service. At present, it's used as a way to refine the description of information system quality of service in the IS field. Researchers and practitioners try to explore users' perception of service quality in an information system environment, or to verify the applicability of these five dimensions for certain objects (such as e-commerce websites, information systems within the organization), or to extend the five dimensions based on the use of information systems (Parasuraman et al., 2005; Zeithaml, Parasuraman \& Malhotra,2002). For information system, the main meaning of these dimensions as follows:

1. Tangibles: service providers can update the hardware, software, and information of the information system.

2. Reliability: information systems service provider is trustworthy.

3. Responsiveness: information systems service provider can provide services in a timely manner.

4. Assurance: information service providers have sufficient knowledge and ability to do a good job.

5. Empathy: information systems service providers have the best enthusiasm and patience to the customer.

Although the basic model of information system service quality was put forward on previous researches, there is lack of in-depth and detailed study on system quality, information quality and service quality. According to the characteristics of e-government services, this study combines service quality dimensions of SERQUAL and IS success model, and makes a further refinement on IS Success Model's three dimensions, in order, system quality, information quality and service quality. Given full consideration to the influence of offline services on online services, a conceptual model is established, which is of great theoretical significance. 


\section{Model and Hypothesis}

\subsection{Online Government Service Quality Perception (ONGSQP)}

The emphasis of e-government services is the "citizen-centric" service model which provides convenience for citizen and to the greatest extent meets the needs of citizens (Aikins \& Krane, 2010). Online government service is the main part of e-government services. However, in terms of the form of users' perception, it's different between e-government services and traditional offline government services. This is because, before citizens using e-government, they often have used offline government services, namely on-site services. Therefore, citizens' satisfaction of e-government services (CS) may come from two aspects: on the one hand, user's response and perception on the e-government system itself; on the other hand, the comparison between citizens' perception of the existing offline government services and that of e-government services (Pieterson \& Ebbers, 2008).

Citizens choose online government services mainly due to their expectations of valuable government services. E-government service quality also depends on the government ability of using information and communication technologies (ICTs), so as to provide citizens with effective and efficient government services. The attention to online service quality perception will help government departments to design better user-centered services delivery systems (Hu et al., 2012).

Thus, we propose the following hypothesis:

H1: Online service quality perception has a positive effect on citizens' satisfaction of e-government services.

\subsection{Offline Government Service Quality Perception (OFGSQP)}

The impact of offline government service quality perception on citizens' satisfaction of e-government services comes from two aspects. First, some e-government services can be selected via online and offline in one of two ways. Users, who are familiar with the process of offline government service, have limited cognitive on the ease of use and usefulness of new e-government systems, and they are easy to form a reliance on offline e-government service channels, thereby weakening their online service quality perception. Instead, when citizens have a full understanding and trust of the convenience, security, stability of e-government system, they can also quickly turn to use online services, thus improving their online service quality perception (Lee, Kim \& Ahn, 2011). Compared with offline government services, online government services not only exist certain opportunities but also exist certain risks. In terms of time and cost saving, online government services is convenient, such as when dealing with 
personal income tax, citizens can download client software at related websites, fill out and submit the report rather than go to the crowded government affairs hall and even face with bad attitude staffs. Meanwhile, online services also allow you to modify and update the information already submitted within a certain time. Citizens in the use of the e-government system, however, citizens are faced with a certain degree of uncertainty in the use of e-government systems such as issues of system stability and information privacy, while they also must spend time and effort learning how to operate the new information system (Hussein et al., 2011). From this perspective, users' perception of offline service quality has a negative offset on their online service quality perception.

Secondly, many government businesses need to use both online and offline services to complete, such as applying for a passport. In this case, online services are complementary with offline services, together forming users' perception of quality of e-government services (Kaufman-Scarborough \& Lindquist, 2002). Offline services quality perception is mainly formed by the interaction between users and government staffs; the work scope of government staffs may not only includes handling the offline business, but also includes the explanation and illustration of the online business. In this process, the offline services quality perception greatly influences user's understanding and trust of online business form, and is the key to deal with the entire business successfully (Lee et al., 2011). From this perspective, users' perception of offline service quality has a positive effect on improving their online service quality perception, thus promoting the comprehensive satisfaction of e-government services quality.

Thus, we propose the following hypotheses:

H2: Offline service quality perception has a positive or negative effect on online service quality perception.

H3: Offline service quality perception has a positive or negative effect on citizens' satisfaction of e-government services.

\subsection{Information Quality - Information Clarity (IC)}

The e-government information service has two key objectives: to convey information to the public and increase government transparency (Ma et al., 2005). The goal of e-government system is to provide useful and required, authoritative, timely, credible and accessible information services (Baker, 2009). Citizens' commonly used e-government information resources include education resources, maps, scientific reports, statistical reports, historical data, population data, legal information, medical information, and some specific information needed in handling interaction business of e-government (Burroughs,2009). Users' evaluation on information quality may affect their satisfaction of e-government services as well as the expected usefulness of e-government services (Wu, Liu, Wang \& Wang,2013). Because objects 
of this research are mainly government systems providing specific services, we choose information clarity as a key factor in the information quality.

Chinese citizens generally have high trust on official information on government websites; in this case, it becomes particularly important for the government to make information presentation and information content open and clear. Information display clarity refers to the e-government system has facilitated information query paths, allowing users to easily obtain the information they need (Larsen \& Rainie, 2002). In recent years, the government has made great progress on information services, but if the public really login across all divisions of government portal websites, they may find it difficult to find information about their needed services. People usually search on the Internet through the Baidu (a Chinese search engine), to find their needed government services. Information content clarity mainly refers to information contents such as business guide, handling forms announced by the government website, need to be of clear written expression, easier for users to understand, thus to reduce misunderstanding (McKenna, Tuunanen \& Gardner, 2013). Information clarity of e-government system helps users to form the habit of using e-government system, so as to improve online services quality perception.

Thus, we propose the following hypothesis:

H4: Information clarity of e-government services has a positive effect on the promotion of online service quality perception.

\subsection{System Quality - System Security (SSE) and System Stability (SST)}

System quality refers to the operation characteristic of e-government system itself, and it is a level that includes many factors, including credibility, flexibility, and ease of use and response time (Delone \& McLean, 2003). Because online service is no longer a face-to-face interaction, and information system has become the window of online government services, so the quality of e-government systems became the first impression of users. If citizens believe that e-government system is of high quality, they will tend to always use network systems to submit an application or to get other online government services (Rai, Lang \& Welker, 2002). Therefore, system quality is one of the most important indicators to measure performance of the whole system and user perception. To a large extent, system quality determines citizens' trust in e-government services (Lin et al., 2011). In this paper, system quality is confined to system security and stability.

Youakim and Jean (2007) point out that risk management is an important part of any information system management process, because the control of the security can protect the privacy of users' information to the minimum risk. When citizens and enterprises use e-government, it involves a lot of important information about personal, financial information 
and other private information. Disclosure of government information may lead to citizens' personal insecurity and enterprise technology leaks. Therefore, the control of system security is a key factor to evaluate the quality of the system. For first-time users of e-government, system security is one of the most important preconditions.

Functionally, system stability is one of the key factors affecting the quality of e-government services, refers to whether the system is running smoothly, continuously and fast. Mutual adaptation between system stability and the Internet environment or other information systems plays a key role for evaluation of system quality (Tsai, Lee, Shen \& Lin, 2012). Therefore, service quality is the leading factor in customer satisfaction in the online environment. Users' expectation of system stability will increase or reduce users' satisfaction of the information system, especially in the case of repeated use (Kumar, Maheshwari \& Kumar, 2003).

Thus, we propose the following hypotheses:

H5: System security has positive effect on online service quality perception.

H6: System stability has positive effect on online service quality perception.

\subsection{Service Quality - Interactive Services (IS) and "One-stop" Services (OS)}

Service quality refers to all the services provided by the government through the system, including interactive services, "one-stop" services, rapid services, convenient services, and many other aspects (Pho \& Tambo, 2014). In the study of service quality, this paper confined it to interactive services and "one-stop" services. According to the e-government maturity model, generally includes four stages of the development of e-government, interactive services and one-stop services respectively in the third and fourth stages, which belong to the advanced stage of e-government development (Layne \& Lee, 2001). A mature e-government should be a two-way interactive service. These businesses generally includes personal tax, license application and update, fines, birth/marriage/death declaration, etc; enterprise registration, application of tax, customs, foreign exchange reporting and patent filing, quality inspection, etc.

The focus of e-government services is to link up government internal systems and external online interfaces, and allow users to deal with e-government services; at the same time, e-government system means to provide more comprehensive interactive services for enterprises and citizens, so as to make the business to be dealt more efficiently (Hu et al., 2012). Interactive service is the first step towards true e-government, and is also the key driving factor to replace offline services with online services (Layne \& Lee, 2001). 
Most government services cannot be handled only through one government department, for example, enterprise registration in China should be approved by three government departments, respectively, the ministry of Industry and Commerce, taxation authority, and quality supervision. The design of e-government system should be convenience-oriented and targeted to meet the needs of users, thereby increasing users' intention to use. Based on this goal, in recent years, a lot of work has been done on information sharing across departments and interdepartmental synergy business (Fan et al., 2014). E-government system is designed as the pipe type commonly, to provide convenient and time-saving services by optimizing the business process to the customer (Carter \& Bélanger, 2005).

Thus, we propose the following hypotheses:

H7: Interactive services have a positive effect on online service quality perception.

H8: "One-stop" services have a positive effect on online service quality perception.

Based on the hypotheses above, on the basis of two channels: online and offline services, we set up the Conceptual Model of E-government Services Quality as Figure 3.

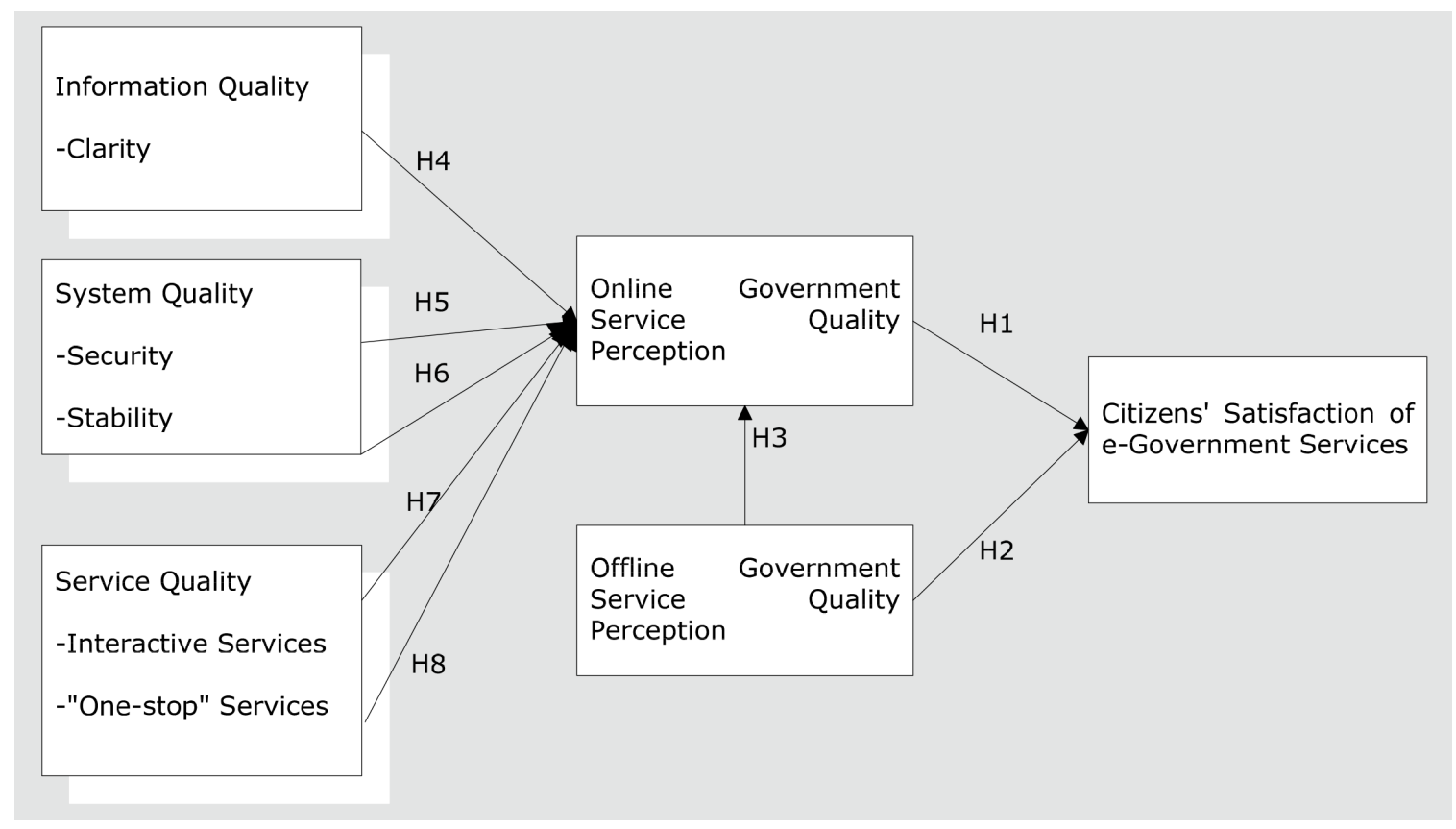

Figure 3. Conceptual model of e-government services quality 


\section{Research Methodology}

\subsection{Questionnaire Design}

This paper conducted an empirical research on current users of e-government. The questionnaire consists of two parts. The first part mainly includes basic demographic information on respondents, such as gender, age, time online, education, occupation and used what e-government services, etc. The second part examines the measurement of variables in the model. All measurements are taken from the previous studies. Satisfaction of e-government services, online service quality perception and offline service quality perception referred to the SERQUAL scale (Lee et al., 2011; Pieterson \& Ebbers, 2008; Reddick \& Turner,2012); measurement items of information clarity here referred to those of Nicolaou, Ibrahim and Van Heck (2013); measurement items of system safety and stability here referred to those of Glover and Benbasat (2010), Lin, Fofanah and Linang (2011), as well as Nicolaou, Ibrahim and Van Heck (2013); interactive services and "one-stop" services here referred to those of Klischewski and Scholl (2008) and Papadomichelaki, Magoutas, Halaris, Apostolou and Mentzas (2006).

In order to ensure the face validity of the questionnaire, respectively government information department staffs, e-government system developers, professors in the field of MIS, professors and $\mathrm{PhD}$ students in the field of service science are asked to read and refine the questionnaire. Based on their feedback, we fixed a few items to make it better reflect the purpose of this study. The pre-test shows all the items are in good validity. This questionnaire adopts five-point Likert scales.

\subsection{Sample Selection}

Samples of this questionnaire mainly are people having e-government system using experience. Through the written form, mail form and network media, the survey finally yielded 336 responses, with 309 valid questionnaires. Table 1 shows specific statistical data. The sample of this study must comply with a condition: respondents must use the e-government system to handle some services, and not just to view and browse government websites. Judging from written questionnaires, e-government websites which are usually used by respondents mostly distributed in household registration system, the Ministry of Education personnel deployment management network platform, National Scholarship Council application platform, Beijing primary school enrollment data collection system, Beijing social security online services platform, Beijing construction committee real estate transaction management platform, personal income tax services management information system and other personal services; besides, registration of enterprises, corporate tax, export customs clearance, statistical data submission, patent filing and other corporate operations. 
From the demographic variables in Table 1, about $70 \%$ of users are under the age of 45 , more than $70 \%$ of users have a bachelor degree or above, the time accessible to the Internet is more than 4 hours every day. This shows that samples are familiar with the Internet, and their ability to accept e-government services is good. At the same time, there are many people using laptop computers, desktop computers and mobile to surf the Internet, so a good availability of government portal websites in various online tools is very important.

\begin{tabular}{|c|c|c|c|c|c|}
\hline Items & Types & Percentage & Items & Types & Percentage \\
\hline \multirow{2}{*}{ Gender } & Male & $44.4 \%$ & \multirow{4}{*}{ OnlineTime } & $<2$ & $4.1 \%$ \\
\hline & Female & $39.6 \%$ & & $2-4$ & $47.9 \%$ \\
\hline \multirow{5}{*}{ Age } & $<20$ & $5.6 \%$ & & $4-8$ & $35.5 \%$ \\
\hline & $20-30$ & $62.5 \%$ & & $>8$ & $12.4 \%$ \\
\hline & $30-45$ & $12.5 \%$ & \multirow{7}{*}{ Occupation } & Student & $44.6 \%$ \\
\hline & $45-55$ & $3.3 \%$ & & Government staff & $13.2 \%$ \\
\hline & $>55$ & $0.8 \%$ & & Company employee & $35.5 \%$ \\
\hline \multirow{4}{*}{ Online Tool } & Desktop computer & $47.9 \%$ & & Individual business & $4.1 \%$ \\
\hline & Laptop computer & $71.9 \%$ & & Migrant worker & $0.8 \%$ \\
\hline & Mobile & $59.5 \%$ & & Unemployed & $0.8 \%$ \\
\hline & Ipad & $4.1 \%$ & & Retiree & $0.8 \%$ \\
\hline \multirow[t]{3}{*}{ Education } & High school & $9.7 \%$ & & & \\
\hline & Undergraduate & $56.9 \%$ & & & \\
\hline & Master & $20.7 \%$ & & & \\
\hline
\end{tabular}

Table 1. Characteristics of the samples

\section{Data Analysis}

\subsection{Measurement Model}

This study employs goodness-of-fit indexs including APC, ARS and AVIF to test the overall fitting of the SEM model. Due to the APC and ARS of the model are significant $(p<0.001)$, and AVIF is less than 5 , indicating the overall fitting of the model meets the requirement (Table 2 ).

\begin{tabular}{|c|c|}
\hline Index & Model \\
\hline APC & $0.257, \quad \mathrm{p}<0.001$ \\
\hline ARS & $0.694, \quad \mathrm{p}<0.001$ \\
\hline AVIF & $1.784, \quad$ Good if $<5$ \\
\hline
\end{tabular}

Table 2. Model fit indices and $\mathrm{P}$ values 


\subsection{Reliability and Validity Analysis}

The measurement model in PLS is used to assess the construct reliability, convergent validity, and discriminant validity of the instruments. We evaluated the measurement scales using the three criteria suggested by Fornell and Larcker (1981). Construct reliability was assessed by two measurement indicators: Cronbach's Alpha and composite reliability. It is generally believed that a value for both exceeded 0.7 , indicating strong reliability. Table 3 shows the reliability.

Convergent validity was assessed by the following three measurement indicators: (1) item loading of each potential variable must be greater than 0.5 (see Table 5); (2) the average variance extraction (AVE) of each potential variable must be greater than 0.5 (see Table 4); (3) the component reliability of each potential variable must be greater than 0.7 (see Table 4). Data shows our scale had good convergent validity.

Discriminant validity was assessed by the following two measurement indicators: (1) the square root of AVE values of each potential variable must be greater than the correlation coefficient between it and other potential variables (see Table 4); (2) item loading of each potential variable must be greater than its cross loading on other potential variables (see Table 5). Data shows our scale had good discriminant validity.

\begin{tabular}{|c|c|c|c|c|}
\hline Variables & Items & Composite reliability & AVE & Cronbach'a \\
\hline IC & 3 & 0.895 & 0.740 & 0.824 \\
\hline SSE & 3 & 0.887 & 0.723 & 0.807 \\
\hline SST & 4 & 0.902 & 0.754 & 0.836 \\
\hline IS & 6 & 0.915 & 0.643 & 0.888 \\
\hline OS & 3 & 0.867 & 0.687 & 0.769 \\
\hline OFGSQP & 2 & 0.914 & 0.842 & 0.813 \\
\hline ONGSQP & 3 & 0.857 & 0.666 & 0.749 \\
\hline CS & 3 & 0.913 & 0.777 & 0.857 \\
\hline
\end{tabular}

Table 3. Convergent validity analysis

\begin{tabular}{|c|c|c|c|c|c|c|c|c|}
\hline Variables & IC & SSE & SST & IS & OS & OFGSQP & ONGSQP & CS \\
\hline IC & $(0.860)$ & 0.571 & 0.556 & 0.621 & 0.551 & 0.117 & 0.613 & 0.600 \\
\hline SSE & 0.571 & $(0.851)$ & 0.502 & 0.567 & 0.513 & 0.078 & 0.570 & 0.545 \\
\hline SST & 0.556 & 0.502 & $(0.868)$ & 0.626 & 0.652 & 0.323 & 0.573 & 0.637 \\
\hline IS & 0.621 & 0.567 & 0.626 & $(0.802)$ & 0.615 & 0.417 & 0.701 & 0.733 \\
\hline OS & 0.551 & 0.513 & 0.652 & 0.615 & $(0.829)$ & 0.212 & 0.681 & 0.619 \\
\hline OFGSQP & 0.117 & 0.078 & 0.323 & 0.417 & 0.212 & $(0.918)$ & 0.408 & 0.386 \\
\hline ONGSQP & 0.613 & 0.570 & 0.573 & 0.701 & 0.681 & 0.408 & $(0.816)$ & 0.814 \\
\hline CS & 0.600 & 0.545 & 0.637 & 0.733 & 0.619 & 0.386 & 0.814 & $(0.882)$ \\
\hline
\end{tabular}

Table 4. Construct correlations with the square root of AVE along the diagonals 


\begin{tabular}{|c|c|c|c|c|c|c|c|c|}
\hline Variables & IC & SSE & SST & IS & os & OFGSQP & ONGSQP & CS \\
\hline IC1 & $(0.875)$ & 0.423 & 0.521 & 0.487 & 0.485 & 0.110 & 0.535 & 0.517 \\
\hline IC2 & $(0.863)$ & 0.548 & 0.414 & 0.538 & 0.425 & 0.109 & 0.569 & 0.483 \\
\hline IC3 & $(0.842)$ & 0.504 & 0.500 & 0.579 & 0.514 & 0.083 & 0.478 & 0.549 \\
\hline SSE1 & 0.464 & $(0.885)$ & 0.407 & 0.429 & 0.473 & 0.077 & 0.464 & 0.464 \\
\hline SSE2 & 0.603 & $(0.783)$ & 0.434 & 0.557 & 0.422 & 0.035 & 0.521 & 0.487 \\
\hline SSE3 & 0.405 & $(0.880)$ & 0.443 & 0.471 & 0.415 & 0.085 & 0.477 & 0.445 \\
\hline SST1 & 0.579 & 0.546 & $(0.898)$ & 0.561 & 0.605 & 0.211 & 0.559 & 0.606 \\
\hline SST2 & 0.423 & 0.475 & $(0.854)$ & 0.535 & 0.662 & 0.216 & 0.524 & 0.557 \\
\hline SST3 & 0.441 & 0.280 & $(0.852)$ & 0.534 & 0.431 & 0.418 & 0.407 & 0.494 \\
\hline IS1 & 0.552 & 0.257 & 0.516 & $(0.735)$ & 0.401 & 0.411 & 0.474 & 0.600 \\
\hline IS2 & 0.548 & 0.488 & 0.499 & $(0.862)$ & 0.521 & 0.378 & 0.584 & 0.592 \\
\hline IS3 & 0.507 & 0.556 & 0.423 & $(0.838)$ & 0.419 & 0.363 & 0.620 & 0.603 \\
\hline IS4 & 0.573 & 0.603 & 0.583 & $(0.833)$ & 0.529 & 0.237 & 0.623 & 0.654 \\
\hline IS5 & 0.479 & 0.380 & 0.509 & $(0.815)$ & 0.541 & 0.373 & 0.556 & 0.555 \\
\hline IS6 & 0.315 & 0.420 & 0.489 & $(0.718)$ & 0.551 & 0.245 & 0.504 & 0.526 \\
\hline OS1 & 0.457 & 0.404 & 0.596 & 0.567 & $(0.868)$ & 0.186 & 0.545 & 0.491 \\
\hline OS2 & 0.484 & 0.497 & 0.605 & 0.609 & $(0.881)$ & 0.197 & 0.621 & 0.599 \\
\hline os3 & 0.430 & 0.369 & 0.403 & 0.327 & $(0.729)$ & 0.142 & 0.528 & 0.442 \\
\hline OFGSQP1 & 0.069 & 0.036 & 0.291 & 0.361 & 0.197 & $(0.918)$ & 0.348 & 0.329 \\
\hline OFGSQP2 & 0.146 & 0.108 & 0.302 & 0.405 & 0.193 & $(0.918)$ & 0.401 & 0.380 \\
\hline OFGSQP3 & 0.489 & 0.460 & 0.479 & 0.537 & 0.631 & 0.343 & $(0.833)$ & 0.638 \\
\hline ONGSQP1 & 0.509 & 0.519 & 0.383 & 0.606 & 0.440 & 0.286 & $(0.784)$ & 0.623 \\
\hline ONGSQP2 & 0.505 & 0.421 & 0.537 & 0.575 & 0.591 & 0.368 & $(0.830)$ & 0.731 \\
\hline CS1 & 0.537 & 0.465 & 0.554 & 0.625 & 0.550 & 0.299 & 0.609 & $(0.851)$ \\
\hline CS2 & 0.524 & 0.468 & 0.606 & 0.677 & 0.570 & 0.419 & 0.790 & $(0.893)$ \\
\hline CS3 & 0.527 & 0.508 & 0.526 & 0.638 & 0.518 & 0.303 & 0.749 & $(0.900)$ \\
\hline
\end{tabular}

Table 5. Item Loadings and cross loading

\subsection{Analysis of the Structure Equation Model (SEM)}

We used WarpPLS3.0 to conduct SEM analysis. Figure 4 shows the overall explanatory power of the model as well as t-test results of all paths. According to views of Falk and Miller (1992), R2 must be at least above 0.1 . Here the R2 value of online service quality perception and R2 of public satisfaction of e-government respectively is 0.70 and 0.68 , which means that these explanatory variables explained $70 \%$ of online service quality perception and online service quality perception explained $68 \%$ of citizens' satisfaction of e-government.

Results show that online service quality perception has a positive effect on citizens' satisfaction of e-government services, so $\mathrm{H} 1$ is supported. At the same time, results show that has a significant effect on citizens' satisfaction of e-government services, so H3 is supported. However, the impact of offline service quality perception on citizens' satisfaction of 
e-government services is not significant, and there is some degree of positive impact, so $\mathrm{H} 2$ is not supported.

Information clarity, system security, interactive services and "one-stop" services have a significant positive influence on online service quality perception, so $\mathrm{H} 4, \mathrm{H} 5, \mathrm{H} 7$ and $\mathrm{H} 8$ are supported. However, system stability does not have a significant effect on online service quality perception, so $\mathrm{H} 6$ is not supported.

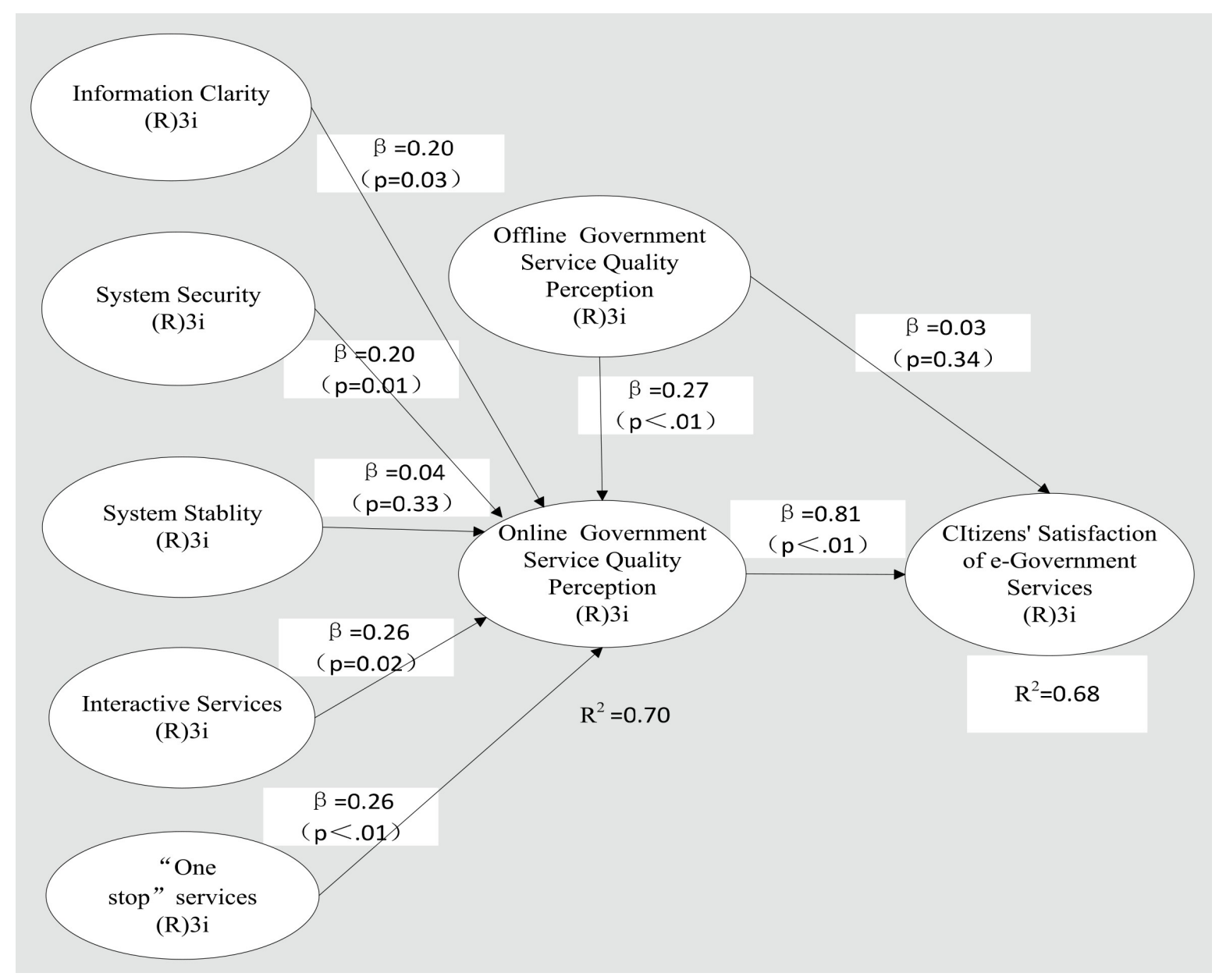

Figure 4. SEM analysis results

\section{Analysis and Findings}

From the aspects of online service quality perception and offline service quality perception, based on IS Success model and SERQUAL model, e-government services quality model has been built in this paper.

Online service quality is under the common function of three variables, respectively, information quality, system quality and service quality. For further in-depth discussion, the 
study extracts the key features of the above three variables. For information quality, the emphasis is on the clarity of the e-government information. Internet has become the main source of information. There are huge amounts of new information every day, then, how to find useful content from information easy and fast, becoming particularly critical. In China, it's not easy for the public to find some online services of the government, so they often need to first search in Baidu, and then identify and pick up the right ones from many results. Therefore, the clarity of the e-government information not only refers to articulate the business information itself, also includes clarity of the acquisition path of information.

For system quality, this article focuses on two variables: security and stability. Security is an important factor affecting the quality of e-government services. E-government system must ensure the security and confidentiality of users' information as well as users' submitted information, especially when in the course of handling public business involving privacy information, financial information, confidential information, etc., so as to enhance people's confidence in using e-government systems, promote people's interest to continue to adopt and improve public satisfaction. However, unfortunately, the influence of the stability on quality of online services was not significant. The possible reason may be due to our questionnaires mostly are done by people who live or work in Beijing, Shanghai, Shenzhen and other big cities, in these cities, network stability is relatively affordable, so user concerns about stability is not strong. We can expand the scope of samples to test again in the future. A stable government portal site can guarantee citizens to enjoy e-government services anytime and anywhere. With the popularity of various mobile Internet devices, it will bring opportunities and challenges to the construction of e-government.

For service quality, this article focuses on two variables: interactive services and "one-stop" services. Both the two variables have a significant effect on improving online service quality. Interactive e-government service refers to provide satisfactory services for customers quickly and proactively, solve problems, respond to questions, as well as the ability to provide personalized services, including three aspects: improving efficiency, active understanding of user needs and providing personalized services according to different user requirements. Currently China is building many e-government projects in promoting information sharing among different government departments, systems integration and business synergies. One purpose of these projects is to provide "one-stop" services of e-government for the public, which also is the highest goal of e-government projects.

Consistent with previous research conclusions, online government service quality perception has a significant influence on the public satisfaction. Online government service quality perception can be obtained from the following aspects: (1) submit an application online and output online, save time for citizens by not going to the scene; (2) clear system design, good business process and ease of use; (3) online services avoid poor attitude of staffs at onsite 
services. Good online service quality perception will greatly promote the public to reuse e-government channels, thus form public satisfaction of e-government.

Research results show that offline service quality perception has a significant positive influence on online government service quality perception, that is to say, the improvement of offline services contributes to citizens' expectations for online government services, thus people are more willing to use and continue to use online government services. It mainly comes from two aspects: first, in tandem case, good offline service quality perception will relieve users' inadaptability of e-government system and users' risk perception; secondly, in coexistence case, staff attitude to users in offline services will directly form a contrast image of that in online government services.

Based on the above discussion, it can be concluded that online government services quality is the most direct factor on public satisfaction of e-government. Offline government service quality via its impact on perception of online services quality, thus indirectly has an impact on public satisfaction. Therefore, the government should focus on improving the e-government online service quality in order to improve the public service satisfaction of e-government services; but this does not mean that the government can ignore the quality of the traditional government services. Good offline services still have a strong influence on improving public perception of online service quality.

\section{Conclusion}

The purpose of this study is to explore the key factors affecting the quality of e-government services, and provide theoretical references for government departments to improve the level of e-government services. From the aspects of online service quality perception and offline service quality perception, based on IS Success model and SERQUAL model, e-government services quality model has been built with information quality, system quality and service quality as key factors. To study the public satisfaction of e-government services quality in actual use, the public including enterprises and citizens who have e-government services using experience were investigated through questionnaire. Finally, in analyzing the collected data, we used SPSS18.0 and WarpPLS3.0 to conduct samples' reliability analysis, validity analysis and structural equation model testing, and determined key factors affecting public satisfaction; thus making a contribution to improve the theory of e-government services.

Due to the limitation of research time and conditions, there are still some shortcomings of this study, pending further study. First, on the selection of the sample, most samples of this study come from big cities, including Beijing, Shanghai, and Shenzhen and so on, whose representative may be insufficient. In the future, research can further expand the scope of the sample to towns and villages, and make comparative studies between different groups of 
people. Secondly, mobile e-government as an important direction of the development of e-government, which was only mentioned in this study, wasn't studied comprehensively. In the future we will study more about mobile e-government services channels.

\section{Acknowledgments}

The work on this paper was supported by the National Science Funds in China (Project number: 71103021, 71403029), Beijing Philosophy and Social Science Planning Project (13JGC085), and Beijing Higher Education Yong Elite Teacher Project (YETP0852).

\section{References}

Aikins, S.K., \& Krane, D. (2010). Are Public officials obstacles to citizen-centered e-government? An examination of municipal administrators' motivations and actions. State and Local Government Review, 42(2), 87-103. http://dx.doi.org/10.1177/0160323X10369159

Akman, I., Yazici, A., Mishra, A., \& Arifoglu, A. (2005). E-government: A global view an empirical evaluation of some attributes of citizens. Government Information Quarterly, 22(2), 239-257. http://dx.doi.org/10.1016/j.giq.2004.12.001

Baker, D.L. (2009). Advancing e-Government performance in the United States through enhanced usability benchmarks. Government Information Quarterly, 26(1), 82-88. http://dx.doi.org/10.1016/j.giq.2008.01.004

Bélanger, F., \& Carter, L. (2008). Trust and risk in e-government adoption. The Journal of Strategic Information Systems, 17(2), 165-176. http://dx.doi.org/10.1016/j.jsis.2007.12.002

Burroughs, J.M. (2009). What users want: Assessing government information preferences to drive information services. Government Information Quarterly, 26(1), 203-218. http://dx.doi.org/10.1016/j.giq.2008.06.003

Cardozo, R.N. (1965) An experimental study of customer effort, expectation and satisfaction. Journal of Marketing Research, 3(2), 244-249. http://dx.doi.org/10.2307/3150182

Carter, L., \& Bélanger, F. (2005). The utilization of e-government services: citizen trust, innovation and acceptance factors. Information Systems Journal, 15(1), 5-25. http://dx.doi.org/10.1111/j.1365-2575.2005.00183.x

Cohen, J.E. (2006). Citizen satisfaction with contacting government on the internet. Information Polity, 11(1), 51-65. 
Delone, W.H., \& McLean, E.R. (2003). The DeLone and McLean model of information systems success: a ten-year update. Journal of Management Information Systems, 19(4), 9-30.

Falk, R.F., \& Miller, N.B. (1992). A primer for soft modeling. Akron: The University of Akron Press.

Fan, J., Zhang, P., \& Yen, D.C. (2014). G2G information sharing among government agencies. Information \& Management, 51(1), 120-128. http://dx.doi.org/10.1016/j.im.2013.11.001

Fornell, C., \& Larcker, D.F. (1981). Evaluating structural equation models with unobservable variables and measurement error. Journal of marketing research, $18(1), 39-50$. http://dx.doi.org/10.2307/3151312

Glover, S., \& Benbasat, I. (2010). A comprehensive model of perceived risk of e-commerce transactions. International Journal of Electronic Commerce, $15(2)$, 47-78. http://dx.doi.org/10.2753/JEC1086-4415150202

Goldfinch, S. (2007). Pessimism, computer failure, and information systems development in the public sector. Public Administration Review, 67(5), 917-929. http://dx.doi.org/10.1111/j.15406210.2007.00778.x

Hu, G., Shi, J., Pan, W., \& Wang, J. (2012). A hierarchical model of e-government service capability: An empirical analysis. Government Information Quarterly, 29(4), 564-572. http://dx.doi.org/10.1016/j.giq.2012.04.007

Hung, S.Y., Chang, C.M., \& Kuo, S.R. (2013). User acceptance of mobile e-government services: An empirical study. Government Information Quarterly, 30(1), 33-44. http://dx.doi.org/10.1016/j.giq.2012.07.008

Hussein, R., Mohamed, N., Ahlan, A.R., \& Mahmud, M. (2011). E-government application: an integrated model on G2C adoption of online tax. Transforming Government: People, Process and Policy, 5(3), 225-248. http://dx.doi.org/10.1108/17506161111155388

Kaufman-Scarborough, C., \& Lindquist, J.D. (2002). E-shopping in a multiple channel environment. Journal of Consumer Marketing, 19(4), 333-350. http://dx.doi.org/10.1108/07363760210433645

Klischewski, R., \& Scholl, H.J. (2008). Information quality as capstone in negotiating e-government integration, interoperation and information sharing. Electronic Government, an International Journal, 5(2), 203-225. http://dx.doi.org/10.1504/EG.2008.016647

Kumar, V., Maheshwari B., \& Kumar, U. (2003). An investigation of critical management issues in ERP implementation: empirical evidence from Canadian organizations. Technovation, 23(10), 793-807. http://dx.doi.org/10.1016/S0166-4972(02)00015-9 
Larsen, E., \& Rainie, L. (2002). The rise of the e-citizen: How people use government agencies' web sites. Washington, DC: Pew internet \& American life project.

Layne, K., \& Lee, J. (2001). Developing fully functional E-government: A four stage model. Government Information Quarterly, 18(2), 122-136. http://dx.doi.org/10.1016/S0740-624X(01)00066-1

Lee, J., Kim, H.J., \& Ahn, M.J. (2011). The willingness of e-Government service adoption by business users: The role of offline service quality and trust in technology. Government Information Quarterly, 28(2), 222-230. http://dx.doi.org/10.1016/j.giq.2010.07.007

Lin, F., Fofanah, S.S., \& Liang, D. (2011). Assessing citizen adoption of e-Government initiatives in Gambia: A validation of the technology acceptance model in information systems success. Government Information Quarterly, 28(2), 271-279.

http://dx.doi.org/10.1016/j.giq.2010.09.004

Luna-Reyes, L.F., Gil-Garcia, J.R., \& Cruz, C.B. (2007). Collaborative digital government in Mexico: Some lessons from federal Web-based interorganizational information integration initiatives. Government Information Quarterly, 24(4), 808-826.

http://dx.doi.org/10.1016/j.giq.2007.04.003

Ma, L., Chung, J., \& Thorson, S. (2005). E-government in China: Bringing economic development through administrative reform. Government Information Quarterly, 22(1), 20-37. http://dx.doi.org/10.1016/j.giq.2004.10.001

McKenna, B., Tuunanen, T., \& Gardner, L. (2013). Consumers' adoption of information services. Information \& Management, 50(5), 248-257. http://dx.doi.org/10.1016/j.im.2013.04.004

Morgeson, F.V., \& Mithas, S. (2009). Does E-Government measure up to E-business? Comparing end user perceptions of US federal government and E-business web sites. Public Administration Review, 69(4), 740-752. http://dx.doi.org/10.1111/j.1540-6210.2009.02021.x

Nicolaou, A.I., Ibrahim, M., \& Van Heck, E. (2013). Information quality, trust, and risk perceptions in electronic data exchanges. Decision Support Systems, 54(2), 986-996. http://dx.doi.org/10.1016/j.dss.2012.10.024

Osman, I.H., Anouze, A.L., Hindi, N.M., Irani, Z., Lee, H., \& Weerakkody, V. (2014). I-meet framework for the evaluation e-Government services from engaging stakeholders' perspectives. European Scientific Journal, 10(10), 1-10.

Otjacques, B., Hitzelberger, P., \& Feltz, F. (2007). Interoperability of e-government information systems: Issues of identification and data sharing. Journal of Management Information Systems, 23(4), 29-51. http://dx.doi.org/10.2753/MIS0742-1222230403 
Papadomichelaki, X., Magoutas, B., Halaris, C., Apostolou, D., \& Mentzas, G. (2006). A review of quality dimensions in e-government services. M.A. Wimmer et al. (Eds.). EGOV 2006. Springer-Verlag Berlin Heidelberg (4048), 128-138. http://dx.doi.org/10.1007/11823100_12

Parasuraman, A., Zeithaml, V.A., \& Malhotra, A. (2005). ES-QUAL a multiple-item scale for assessing electronic service quality. Journal of service research, 7(3), 213-233. http://dx.doi.org/10.1177/1094670504271156

Pardo, T.A., \& Tayi, G.K. (2007). Interorganizational information integration: A key enabler for digital government. Government Information Quarterly, 24(4), 691-715.

http://dx.doi.org/10.1016/j.giq.2007.08.004

Pho, H.T., \& Tambo, T. (2014). Integrated management systems and workflow-based electronic document management: An empirical study. Journal of Industrial Engineering and Management, 10(1), 194-217. http://dx.doi.org/10.3926/jiem.846

Pieterson, W., \& Ebbers, W. (2008). The use of service channels by citizens in the Netherlands: Implications for multi-channel management. International Review of Administrative Sciences, 74(1), 95-110. http://dx.doi.org/10.1177/0020852307085736

Rai, A., Lang, S.S., \& Welker, R.B. (2002). Assessing the validity of IS success models: An empirical test and theoretical analysis. Information systems research, 13(1), 5069.http://dx.doi.org/10.1287/isre.13.1.50.96

Reddick, C.G., \& Turner, M. (2012). Channel choice and public service delivery in Canada: Comparing e-Government to traditional service delivery. Government Information Quarterly, 29(1), 1-11. http://dx.doi.org/10.1016/j.giq.2011.03.005

Tang, X.P., Wu, Q.L., \& Zhang, P.Z. (2007). Study on the needs of e-Government for the public in China. E-Government, 4(9), 15-20. (In Chinese)

Tsai, W.H., Lee, P.L., Shen, Y.S., \& Lin, H.L. (2012). A comprehensive study of the relationship between enterprise resource planning selection criteria and enterprise resource planning system success. Information \& Management, 49(1), 36-46.

http://dx.doi.org/10.1016/j.im.2011.09.007

Wang, L., Bretschneider, S., \& Gant, J. (2005). Evaluating web-based e-government services with a citizen-centric approach. Proceedings of the 38th Annual Hawaii International Conference on System Sciences, 1-10. http://dx.doi.org/10.1109/HICSS.2005.252

Wang, Y.K. (2000). Structural adjustment of China's public administration power and its characteristics. The National Academy of Sciences, 2, 49-52. (In chinese.) 
Wang, Y.S., \& Liao, Y.W. (2008). Assessing e-Government systems success: A validation of the DeLone and McLean model of information system success. Government Information Quarterly, 25(4), 717-733. http://dx.doi.org/10.1016/j.giq.2007.06.002

Wu, J., Liu, L., Wang, N., \& Wang, Z. (2013). Interorganizational IT capability in China: exploring the differences between state-owned and non-state-owned enterprises. Journal of System and Management Sciences, 3(3), 14-25. http://dx.doi.org/10.1007/978-3-642-32054-5_121

Yang, T.M., \& Maxwell, T.A. (2011). Information-sharing in public organizations: A literature review of interpersonal, intra-organizational and inter-organizational success factors. Government Information Quarterly, 28(2), 164-175. http://dx.doi.org/10.1016/j.giq.2010.06.008

Youakim, B., \& Jean, S. (2007). Security and risk management in supply chins. Journal of information Assurance and Security, 2, 288-296.

Zeithaml, V.A., Parasuraman, A., \& Malhotra, A. (2002). Service quality delivery through web sites: A critical review of extant knowledge. Journal of the academy of marketing science, 30(4), 362-375. http://dx.doi.org/10.1177/009207002236911 


\section{Appendix}

\begin{tabular}{|c|c|}
\hline \multicolumn{2}{|r|}{ Questionnaire } \\
\hline Variables & Items \\
\hline Information Clarity & $\begin{array}{l}\text { 1. The website is equipped with search capability; you can conveniently find items that you } \\
\text { need via keywords. } \\
\text { 2. The categorization of website information and functions are reasonable, you can quickly } \\
\text { find the information and services you need. } \\
\text { 3. The guidance and instructions of the website is clear, easy to understand and operate. }\end{array}$ \\
\hline System Security & $\begin{array}{l}\text { 1. The website will protect users' privacy; I don't have to worry about personal information } \\
\text { being leaked. } \\
\text { 2. The website has users' privacy protection settings, such as password authentication and } \\
\text { mobile authentication. } \\
\text { 3. My submitted information will not be disclosed. }\end{array}$ \\
\hline System Stability & $\begin{array}{l}\text { 1. Images, videos and hyperlinks of the website can be displayed properly. } \\
\text { 2. The use of website services rarely appears system failure. } \\
\text { 3. Website information and services are not restricted by time period. } \\
\text { 4. The content and performance of the website will not be affected by using different } \\
\text { browsers or Internet tools to open government portal websites. }\end{array}$ \\
\hline Interactive Services & $\begin{array}{l}\text { 1. The website has real-time communication channels, such as online customer services. } \\
\text { 2. The website online service or email system, message boards and other channels can reply } \\
\text { me in time and seriously answer my questions and comments. } \\
\text { 3. The website will take the initiative to inform me the new information or services according } \\
\text { to records. } \\
\text { 4. On the basis of meeting the general requirements, the website also provides personalized } \\
\text { custom services for different users. } \\
\text { 5. Online transactions can be completed within a specified time. } \\
\text { 6. After submit relevant materials, online business makes me feel satisfied with the results. }\end{array}$ \\
\hline "One-stop" Services & $\begin{array}{l}\text { 1. When handling cross-sector business, I can only log on one business portal to complete all } \\
\text { procedures of the business } \\
\text { 2. When handling cross-sector business, I can only log on the related government websites } \\
\text { according to business needs, without logging on other government websites of each } \\
\text { separate business sector. } \\
\text { 3. When handling cross-sector business, I only need to care about the process of the } \\
\text { business and don't need to care about who is responsible for specific business. }\end{array}$ \\
\hline $\begin{array}{l}\text { Offline Government } \\
\text { Service Quality } \\
\text { Perception }\end{array}$ & $\begin{array}{l}\text { 1. The function of e-Government is clear. } \\
\text { 2. The e-Government system is safe and reliable. } \\
\text { 3. The e-Government system is integrated with other systems. }\end{array}$ \\
\hline $\begin{array}{l}\text { Online Government } \\
\text { Service Quality } \\
\text { Perception }\end{array}$ & $\begin{array}{l}\text { 1. Offline service of government departments is very efficient. } \\
\text { 2. Government staffs of offline services are professional and enthusiastic. }\end{array}$ \\
\hline $\begin{array}{l}\text { Citizens' Satisfaction } \\
\text { of e-Government } \\
\text { Services }\end{array}$ & $\begin{array}{l}\text { 1. The function of the e-Government system is comprehensive and the process of the e- } \\
\text { Government system is simple. } \\
\text { 2. The e-Government system can improve the efficiency of government services, and } \\
\text { accelerate the pace of business. } \\
\text { 3. Information and services provided by the e-Government system can meet my needs. }\end{array}$ \\
\hline
\end{tabular}

Journal of Industrial Engineering and Management, 2015 (www.jiem.org)

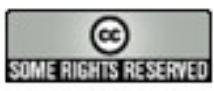

Article's contents are provided on a Attribution-Non Commercial 3.0 Creative commons license. Readers are allowed to copy, distribute and communicate article's contents, provided the author's and Journal of Industrial Engineering and Management's names are included. It must not be used for commercial purposes. To see the complete license contents, please visit http://creativecommons.org/licenses/by-nc/3.0/. 